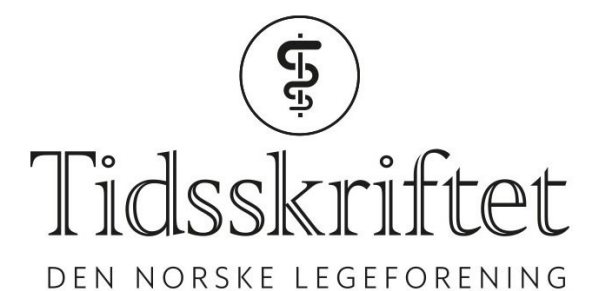

DEN NORSKE LEGEFORENING

\title{
Populær pille med tvilsom historie
}

LEDER

\section{BRITT-INGJERD NESHEIM}

E-post: b.i.nesheim@medisin.uio.no Britt-Ingjerd Nesheim (f. 1942) er pensjonert spesialist i fødselshjelp og kvinnesykdommer. Forfatter har fylt ut ICMJE-skjemaet og oppgir ingen interessekonflikter.

I år er det 50 år siden norske kvinner fikk tilgang til p-pillen.

P-pillen ble registrert i Norge med prevensjon som indikasjon i 1967. I USA hadde den da vært registrert som prevensjonsmiddel i syv år, og flere europeiske land var også tidligere ute enn Norge. Den norske sendrektigheten skyldtes en ikke usunn skepsis hos våre helsemyndigheter mot eventuelle ukjente langtidsvirkninger av et medikament som hadde en så inngripende virkning på kvinnekroppen.

Det var kjent fra dyrefors $\varnothing \mathrm{k}$ fra sent i 1930-årene at progesteron injisert i høye doser hemmet ovulasjonen, men at det ikke var virksomt peroralt. I 1951 lyktes det å syntetisere et stoff med progesteronvirkning som var aktivt peroralt - noretisteron (eller noretindron) (1). Margaret Sanger (1879-1966) var sykepleier, aktivist og forkjemper for kvinners reproduktive rettigheter. Hun oppmuntret biologen Gregory Pincus (1903-67) til å forsøke å utvikle et peroralt prevensjonsmiddel, noe han gjorde i samarbeid med legen John Rock (1890-1984). I 1956 ble det første fors $\varnothing$ ket på mennesker publisert (2), ikke etter, men samtidig med publiseringen av dyrefors $\varnothing \mathrm{k}$. 50 infertilitetspasienter i Boston fikk tre ulike gestagene medikamenter i ulike doser. Det ble rapportert om ovulasjonshemmende effekt, uten vesentlige bivirkninger. Den i dag noe underlige indikasjonen ble forklart ved at progesteron i høye doser tidligere hadde vist gunstig effekt på infertilitet - med henvisning til en artikkel som var «in preparation». Samtidig var prevensjon kontroversielt i USA, så det kan ha vært ønskelig å kamuflere undersøkelsene som infertilitetsbehandling.

Det viste seg at gestagen alene ikke kunne opprettholde endometriet, derfor forsøkte forskerne å legge til østrogen. I 1958 publiserte Pincus og medarbeidere forsøk med ulike doser gestagener og østrogen, brukt både av en gruppe infertile kvinner i Boston og en gruppe kvinner i Puerto Rico (3). Dermed var pillen Enovid født.

I 1961, etter at Enovid var registrert i USA, ble det startet en stor, randomisert undersøkelse i Puerto Rico (4). 9757 kvinner fikk enten Enovid eller mekaniske prevensjonsmidler. Studien ble avsluttet i 1976, fordi den manglet finansiering. Man fant ingen signifikante forskjeller i noen av (de ganske mange) variablene som ble unders $ø$ kt. Men oppfølgingsraten var bare på rundt $24 \%$, og kontinuiteten i prevensjonsbruken var lav. Undersøkelsen ble startet i Puerto Rico fordi det der var lett å finne kvinner som ønsket prevensjon og var villige til å være med, og det var ingen strenge lovbestemmelser. En godt planlagt undersøkelse rant dermed ut i så godt som ingenting, blant annet fordi det ikke var tatt hensyn til deltagernes 
sosiale forhold. At kvinnene, både i denne og i de tidligere undersøkelsene, var svært dårlig informert om hva de var med på, illustrerer i hvor liten grad forskningsetiske prinsipper ble fulgt.

P-pillen viste seg å være et effektivt prevensjonsmiddel, men med potensielt farlige bivirkninger: De første rapportene om tromboembolisk sykdom kom i begynnelsen av 1960-årene. Opp gjennom årene har imidlertid p-pillen fått en rekke nye sammensetninger, og dosene er nå mye lavere enn den gang. En oppsummerende artikkel fra 2015 konkluderer med at med dagens p-piller er oddsratioen for venøs trombose og trombotisk hjerneslag på henholdsvis omkring 3 og 2 (5). Fordi de fortrinnsvis brukes av friske unge kvinner, er den absolutte risikoen svært lav. P-pillen beskytter mot ovariecancer, endometriecancer og kolorektalcancer, men medfører kanskje $ø$ kt risiko for mammacancer, især premenopausalt (5).

I Norge har salget av p-piller steget nokså jevnt siden de kom på markedet (6). En sammenstilling av data fra Folkehelseinstituttet og Statistisk sentralbyrå tilsier at omkring $20 \%$ av kvinner mellom 16 og 44 år bruker pillen i dag $(6,7)$. P-pillebruken har generelt vært lavere i Norge enn i andre land, og spiralbruken har vært høyere. Spiral kom på markedet i Norge omtrent samtidig med p-pillen. Stor aksept for spiral passer godt med det som nå er anbefalingen - nemlig å fremme bruken av langtidsvirkende prevensjon.

Sikker prevensjon, styrt av kvinnen selv, kombinert med god adgang til trygge aborter, har utvilsomt bidratt til ikke bare å styrke kvinners reproduktive helse, men også muligheten til yrkesaktivitet og et selvstendig liv. Medisinsk-etisk sett har p-pillen en lite pen forhistorie. Hadde ikke mulighetene for utprøvning rundt 196o vært mye mindre regulert enn i dag, ville denne utviklingen neppe skjedd, eller den ville tatt mye lengre tid. Det er et tankekors.

Det hevdes ofte at "p-pille» er en forkortelse for Pincus-pille. Jeg har vanskelig for å tro det. Det er bare i Skandinavia det heter p-pille, og det er i skandinaviske språk at prevensjon begynner på p. Det er altså ingen grunn til å gi en mann alene æren for årets jubilant.

LITTERATUR:

1. Djerassi C. Steroid research at Syntex: "the pill" and cortisone. Steroids 1992; 57: 631 - 41. [PubMed][CrossRef]

2. Garcia CR, Pincus G, Rock J. Effects of certain 19-nor steroids on the normal human menstrual cycle. Science 1956; 124: 891-3. [PubMed][CrossRef]

3. Pincus G, Roch J, Garcia CR. Effects of certain 19-nor steroids upon reproductive processes. Ann N Y Acad Sci 1958; 71: 677 - 9o. [PubMed][CrossRef]

4. Potts M, Feldblum PJ, Chi I et al. The Puerto Rico oral contraceptive study: An evaluation of the methodology and results of a feasibility study. Br J Fam Plann 1982; 7: 99 - 103.

5. Bassuk SS, Manson JE. Oral contraceptives and menopausal hormone therapy: relative and attributable risks of cardiovascular disease, cancer, and other health outcomes. Ann Epidemiol 2015; 25:193-200. [PubMed][CrossRef]

6. Legemiddelforbruket i Norge. Folkehelseinstituttet 2017. http://www.legemiddelforbruk.no/ (7.10.2017).

7. Folkemengde og befolkningsendringar. Statistisk sentralbyrå 2017. https://www.ssb.no/befolkning/statistikker/folkemengde/aar-per-1-januar (7.10.2017).

Publisert:30. oktober 2017. Tidsskr Nor Legeforen. DOI: 10.4045/tidsskr.17.0665

(C) Tidsskrift for Den norske legeforening 2020. Lastet ned fra tidsskriftet.no 